\title{
Results of Traditional Manual Therapy on Lower Back Pain as an Alternative to Aggressive Therapy
}

Radnaabazar Molor, Ganbaatar Odontsetseg, Dalh Tseendagva

Radnaabazar Molor Doctorant Medical science, Director of the Sumadi Clinic, e-mail:r.molor@yandex.ru, Otoch Manramba University, 2nd khoroo, Bayanzurkh district, Ulaanbaatar, 13361, Mongolia Contacts: Radnaabazar Molor, e-mail: r.molor@yandex.ru,

orcid.org/0000-0002-0677-693X

\section{Abstract}

Introduction. In briefly to have eight symptoms of Qi disease and very common one which is including all symptoms is Lower back pain. By the WHO research pain here can be intense and is one of the top causes of missed work. This disease has very painful, recurrence and needs period of treatment time, cost expensive. Most of the damages for patients are diagnosis, surgery, pain relief medicines. Thus, we made this theory with practice research on traditional manual therapy for qi originated Lower back pain. Purpose: to compare the traditional diagnostic methods of manual therapy and modern diagnostic methods of X-ray with lower back pain by using assessment of a quality of life developed by WHOQOL.

Materials and methods. 100 patients with lower back pain were examined. The treatment results were evaluated after the application of traditional rhythmic vibration therapy. These treatment results were obtained using traditional diagnostic methods and using radiography of the lower back, which were compared with each other. The WHOQOL questionnaire was used to assess quality of life.

Results and discussion. Therapy was carried out for 10 days. Manual therapy has shown its positive results within a day. Although the anatomical and morphological structure of the lower back showed no significant improvement within 7-10 days of treatment (75\%), but the space of the spine increased ( $80 \%)$, and spinal mobility was asymptomatic (90\%).

Conclusion. Patients treated with manual therapy symptomatically recovered after a year $(60 \%)$. Of 100 patients, they were completely cured by $15 \%$ and improved by $30 \%$.

Keywords: lower back pain, traditional medicine, manual therapy, diagnostic X-ray, musculoskeletal system

For citation: Molor R., Odontsetseg G., Tseendagva D. Results of Traditional Manual Therapy on Lower Back Pain as an Alternative to Aggressive Therapy. Creative Surgery and Oncology. 2020;10(1):39-44. https://doi.org/10.24060/20763093-2020-10-1-39-44 


\section{Результаты традиционной мануальной терапии люмбаго как альтернатива инвазивным методам лечения}

Раднаабазар Молор -

д.м.н., директор клиники

Сумади,

e-mail:r.molor@yandex.ru,

orcid.org/0000-0002-0677-693X

Ганбаатар Одонтсетсег -

к.м.н., директор университе

та Оточ Манрамба,

e-mail:g.odont@yandex.ru,

orcid.org/0000-0002-8072-840X

Далх Тсеендагва -

к.м.н., директор Между-

народного института

монгольской медицины,

e-mail: tseen.g@yandex.ru,

orcid.org/0000-0003-0057-7427
Р. Молор, Г. Одонтсетсег, Д. Тсеендагва

Университет Оточ Манрамба, 2-й хорон, Баянзурх, Улан-Батор, 13361, Монголия

Контакты: Раднаабазар Молор, e-mail: r.molor@yandex.ru

\section{Аннотация}

Введение. В упрощенном виде, существует 8 симптомов недостатка энергии Ци. Самой распространенной болезнью, включающей все эти симптомы, является люмбаго (боль в пояснично-крестцовой области). При этом, согласно ВОЗ, боль может быть очень интенсивной и являться одной из главных причин временной нетрудоспособности. Данная болезнь характеризуется наличием болей, рецидивов, требует периодов восстановления и дорого обходится. Наибольшие траты, понесенные пациентом, включают диагностику, хирургические вмешательства и обезболивающие лекарства. Поэтому мы провели теоретическое и практическое исследование традиционной мануальной терапии люмбаго, вызванного недостатком Ци.

Цель работы: сравнить диагностические результаты традиционной мануальной терапии люмбаго с современными методами рентгенодиагностики путем оценки качества жизни пациентов с использованием опросника WHOQOL.

Материалы и методы. Было обследовано 100 пациентов с люмбаго. Результаты лечения оценивались после применения традиционной ритмической вибрационной терапии. Эти результаты были получены как с использованием традиционных диагностических методов, так и с использованием рентгенодиагностики поясничнокрестцового отдела позвоночника, и сравнены между собой. Опросник WHOQOL использовался для оценки качества жизни.

Результаты и обсуждение. Лечение проводилось в течение 10 дней. Мануальная терапия показала положительный результат за один день. Хотя анатомическая и морфологическая структуры пояснично-крестцового отдела не показали значительных улучшений в течение 7-10 дней лечения (75\%), межпозвонковое пространство увеличилось $(80$ \%) и подвижность позвоночника была бессимптомной $(90 \%)$.

Выводы. Пациенты, которым проводили мануальную терапию, симптоматически восстановились по истечении года (60 \%). Из 100 пациентов полностью вылечились 15 \% и почувствовали улучшение 30 \%.

Ключевые слова: люмбаго, традиционная медицина, мануальная терапия, рентгенодиагностика, костно-мышечная система

Дляцитирования: Молор Р., Одонтсетсег Г., Д. Тсеендагва Д. Результаты традиционной мануальной терапии люмбаго как альтернатива инвазивным методам лечения. Креативная хирургия и онкология. 2020;10(1):39-44. https://doi.org/10.24060/2076-3093-2020-10-1-39-44 


\section{Introduction}

Pain in the lower back takes first place among all non-communicable diseases in terms of the number of years of life lost due to persistent deterioration in health [1]. This pathology most often develops between the ages of 20 and 50, while the most pronounced pain is observed at the age of 50-64 years. In the age range of 20 to 64 years, $24 \%$ of men and $32 \%$ of women suffer from back pain. An alarming fact is that $12-26 \%$ of children and adolescents also complain of lower back pain $[2,3]$.

A number of foreign clinical recommendations suggest that all initially treated patients with lower back pain should be divided into three categories: 1) patients with potentially serious pathology debuting with back pain; 2) patients with radicular pain (radiculopathy) and 3) patients with nonspecific pain in the lower back [4-6].

When treating a patient with pain in the lower back, the doctor's attention should primarily focus on the exclusion of serious pathological conditions in which urgent specialized care is needed $[7,8]$.

In all clinical recommendations for the diagnosis and treatment of nonspecific pain in the lower back, there is no need for laboratory and instrumental methods of research. The use of instrumental examination methods (radiography, magnetic resonance imaging, etc.) for acute pain is indicated in those cases when there is a high risk of developing a serious disease [9-12].

The effectiveness of manual therapy depends on the qualifications of the specialist conducting it. Manual therapy has been shown to have efficacy similar to the use of analgesics, exercise therapy [13].

According to M. Ferreira et al. manual therapy shows slightly better results than placebo therapy, massage, physiotherapeutic procedures and percutaneous electroneurostimulation in case of nonspecific back pain $[14,15]$.

Purpose: to compare the traditional diagnostic methods of manual therapy and modern diagnostic methods of X-ray with lower back pain by using assessment of a quality of life developed by WHOQOL.

\section{Materials and methods}

The study was used clinical research design, and the total of 100 patients with lower back pain were selected. The result of the treatment is estimated on those patients were given the traditional rhythmical vibration therapy in the Sumadi clinic (fig. 1-2). The result of the treatment is compared between traditional diagnostic methods of questioning, observation, touching and modern diagnostic methods of before and post X-ray pictures on lower back pain. The quality of life of the patients is assessed by using a quality of life assessment developed by the WHOQOL.

\section{Results and discussion}

Patients were selected mostly as a young manhood with men and women aged 25 to 45 years old. Of the 100 patients included in the study, 45 were man and 65 were women. We measured three dimensions which used X-ray measurement ruler (fig. 3-5), and each of the measurement taken before and after treatment (fig. 6-8). The treatment continued 10 days.

The reason of lower back pain is caused due to intensity of active and inactive forms of muscle, another word, the spinal columns were narrowed, restricted movement, curved and twisted disorders are common. This matches to the sources of information on the lower back pain disorder for about causes and pathogenesis. Significant improvement of manual therapy is showed around within a day. Although, curved and twisted lower back is not showed significant improvements within 7-10 days treatment $(75 \%)$, but the space of the spinal columns is increased $(80 \%)$, and the spinal mobility were asymptomatic (90\%).

\section{Conclusion}

The patients who have been treated with manual therapy after one year were recovered (60\%), in chronic (35\%), and still dysfunctional (5\%). The result of the treatment is assessed that out of the 100 patients, were cured completely $15 \%$ and improved $30 \%$.

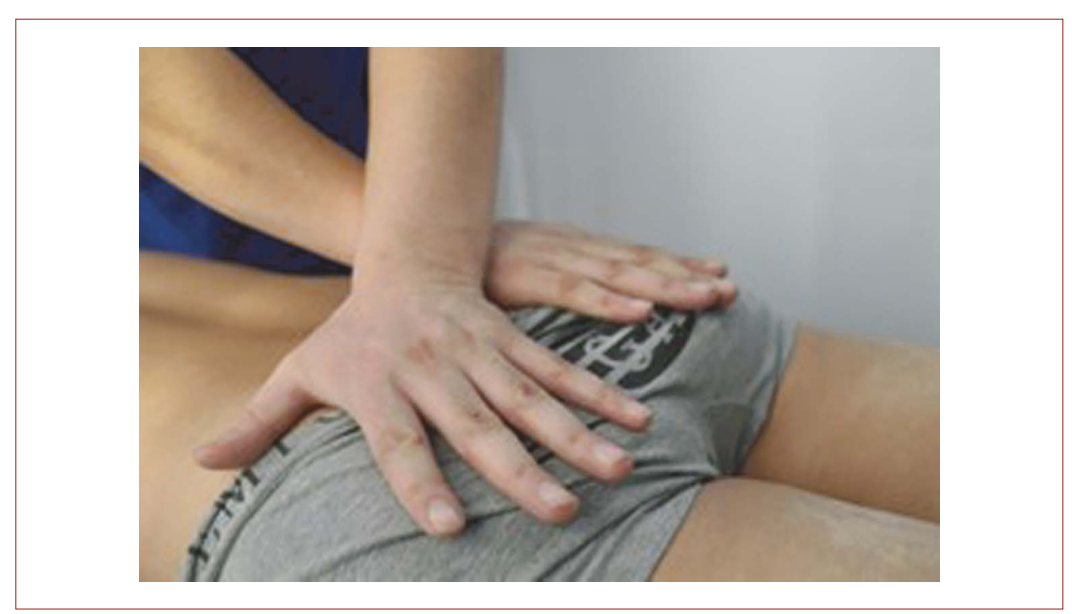

Figure 1. Rhythmical vibration massage

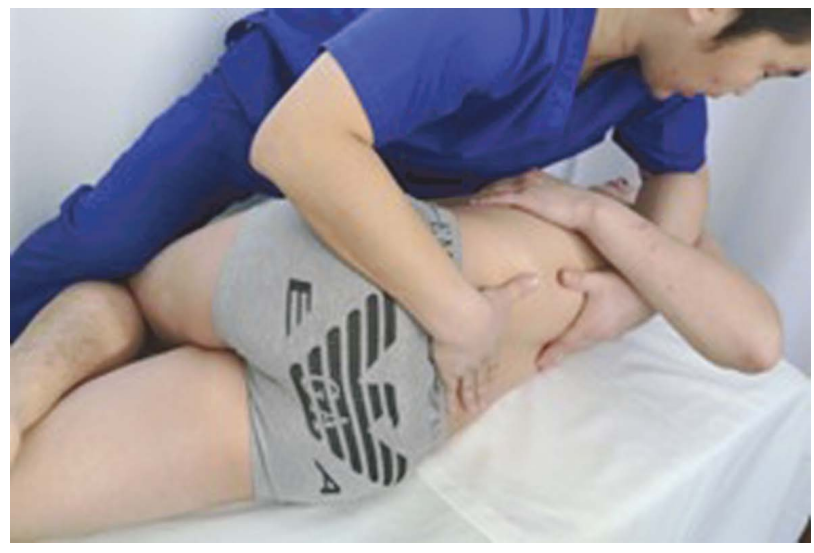

Figure 2. Manipulation treatment 


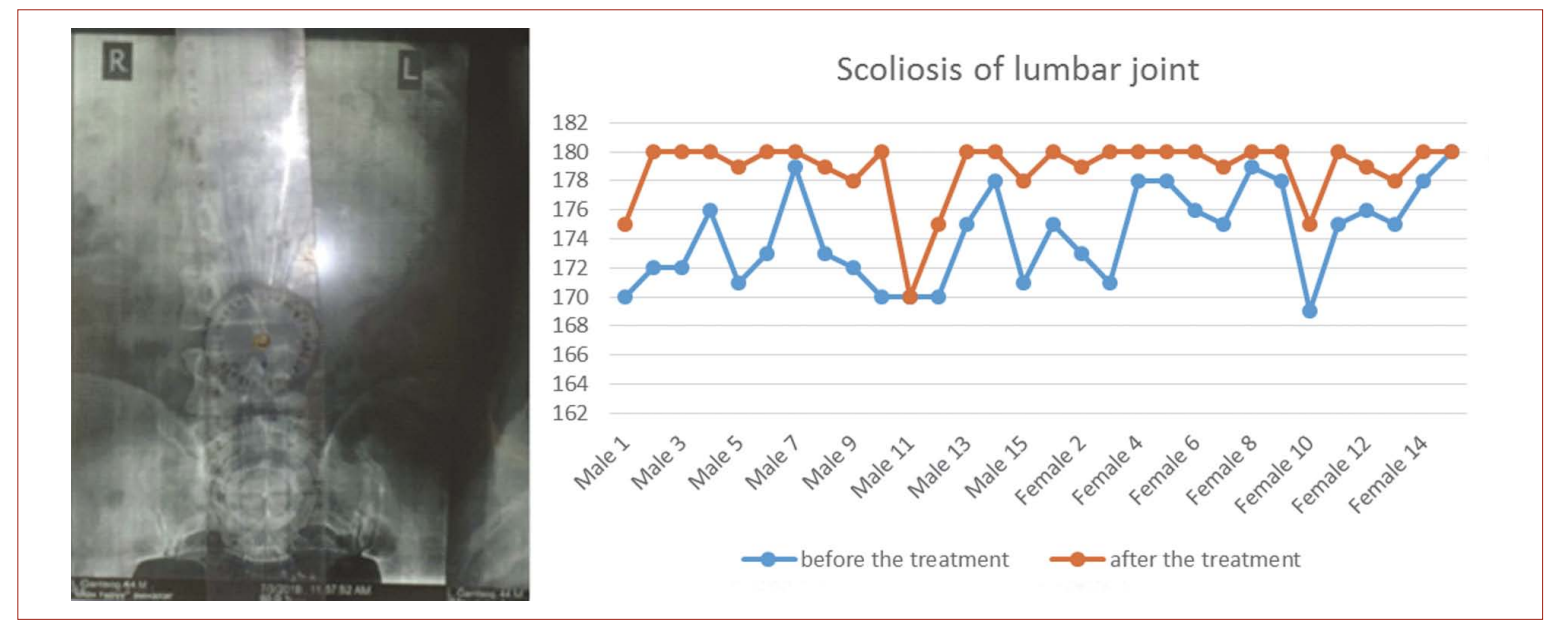

Figure 3. Transversal measurement, size $60 \%$

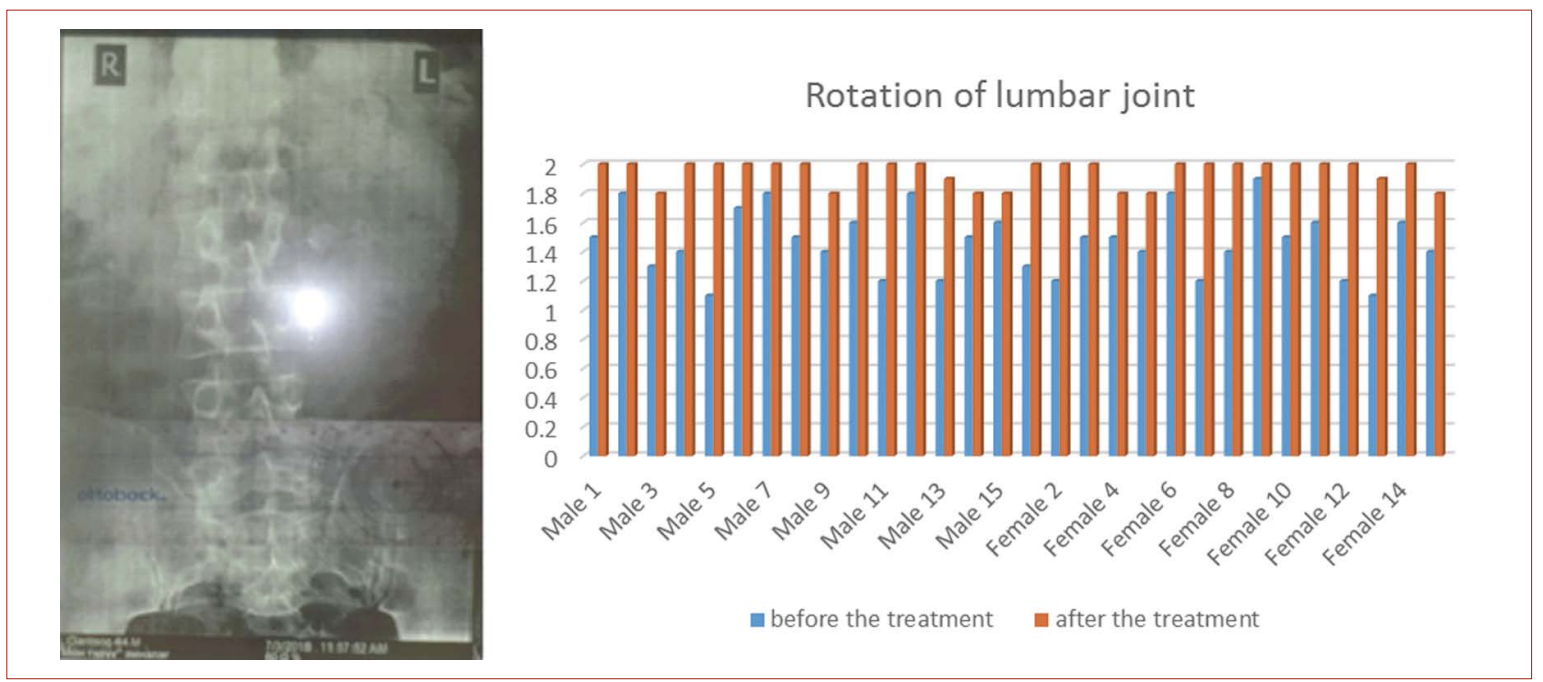

Figure 4. Vertical measurement, size $60 \%$, taken small side

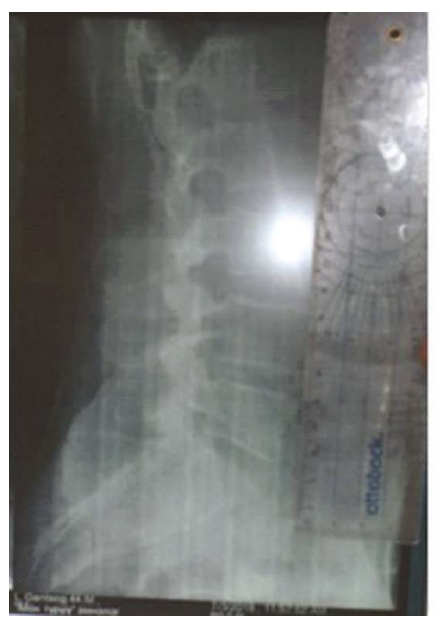

Compression of the vertebral body

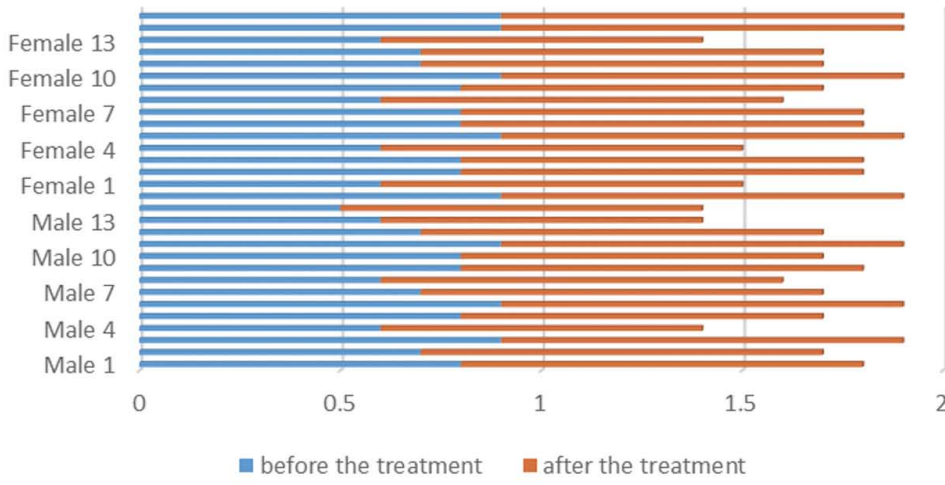

Figure 5. Horizontal measurement, size $60 \%$ 


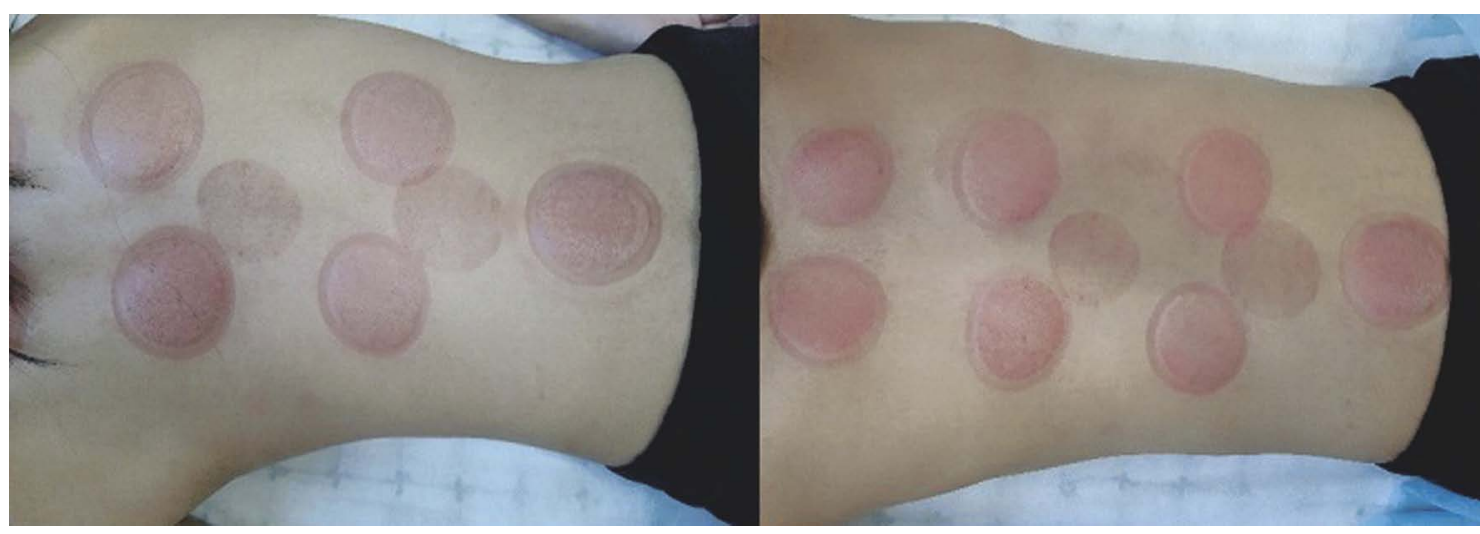

Figure 6. Observation, before and after the treatment (just 1 therapy). Patient 1: female, 13 years old

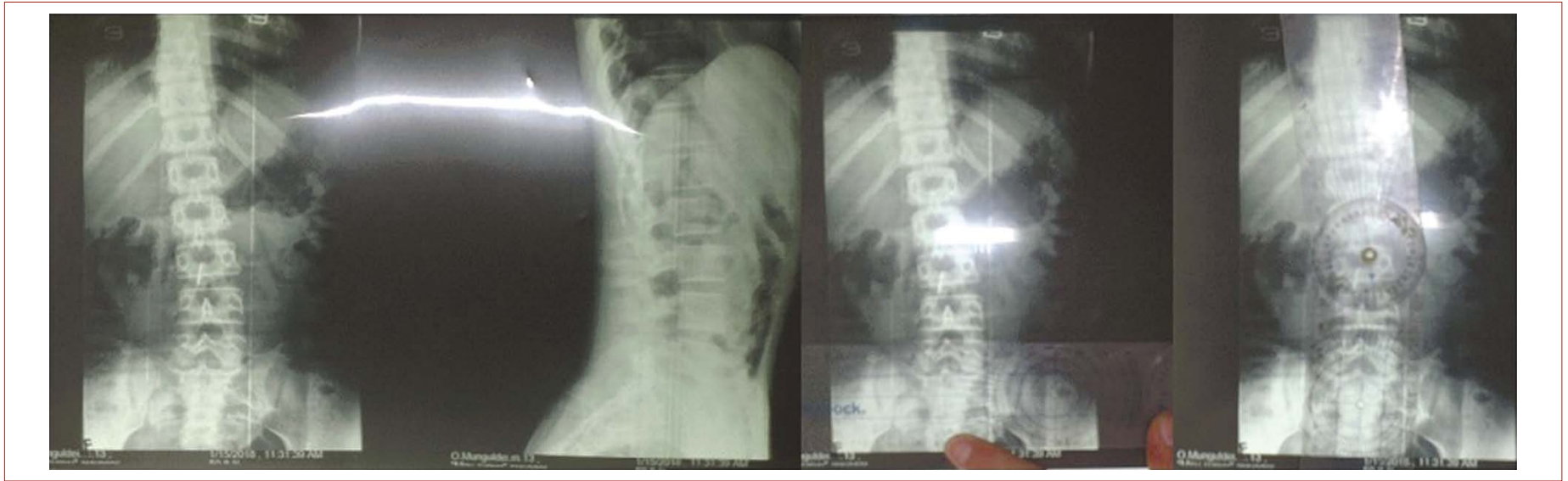

Figure 7. X-ray picture, before the treatment. Patient 1: female, 13 years old

Conflict of interest.

The authors declare no conflict of interest.

Statement of informed consent.

Written informed consent was obtained from the patient for publication of this case report and accompanying materials.

\section{Sponsorship data.}

This work is not funded.

\section{References}

1 Hartvigsen J., Hancock M.J., Kongsted A., Louw Q., Ferreira M.L. Genevay S., et al. What low back pain is and why we need to pay attention. Lancet. 2018;391(10137):2356-67. DOI: 10.1016/S0140 6736(18)30480-X

2 Harms M.C., Peers Ch.E., Chase D. Low back pain: what determines functional outcome at six months? An observational study. BMC Musculoskelet Disord. 2015;11:236. DOI: 10,1186 / 1471-2474-11-236

3 Breen A.C., Carr E., Langworthy J.E., Osmond C., Worswick L. Back pain outcomes in primary care following a practice improvement intervention: a prospective cohort study. BMC Musculoskelet Disord. 2017;12:28. DOI: 10.1186/1471-2474-12-28

4 Van Tulder M., Becker A., Bekkering T., Breen A., del Real M.T., Hutchinson A., et al. Chapter 3. European guidelines for the management of acute nonspecific low back pain in primary care. Eur Spine J. 2016;15(Suppl.2):S169-91. DOI: 10.1007/s00586-006-1071-2

5 Chou R., Qaseem A., Snow V., Casey D., Cross J.T. Jr, Shekelle P., et al. Diagnosis and treatment of low back pain: a joint clinical practice guideline from the American College of Physicians and the

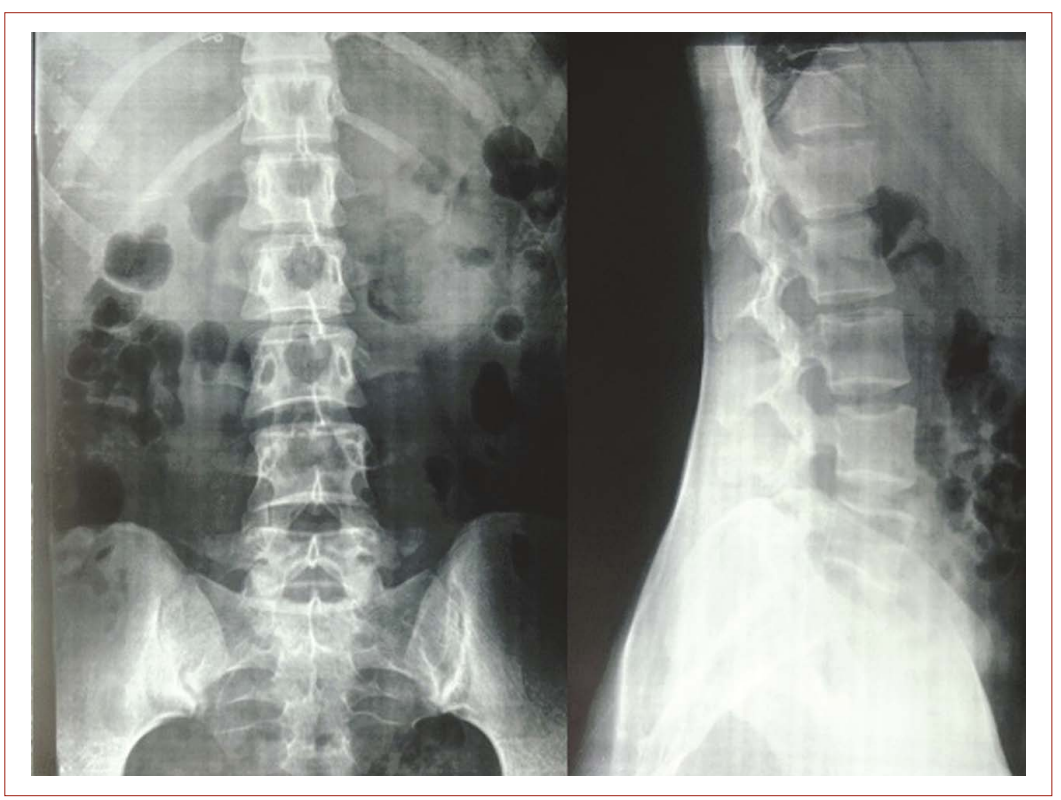

Figure 8. X-ray picture, after the treatment (10 days). Patient 1: female, 13 years old 
American Pain Society. Ann Intern Med. 2017;147(7):478-91. DOI: 10.7326/0003-4819-147-7-200710020-00006

6 Oliveira C.B., Maher C.G., Pinto R.Z., Traeger A.C., Lin C.C., Chenot J.F., et al. Clinical practice guidelines for the management of nonspecific low back pain in primary care: an updated overview. Eur Spine J. 2018;27(11):2791-803. DOI: 10.1007/s00586-018-5673-2

7 Paige N.M., Miake-Lye I.M., Suttorp Booth M., Beroes J.M., Mardian A.S., Dougherty P., et al. Association of spinal manipulative therapy with clinical benefit and harm for acute low back pain: systematic review and meta-analysis. JAMA. 2017;317(14):1451-60. DOI: 10.1001/ jama.2017.3086

8 Gedin F., Skeppholm M., Burström K., Sparring V., Tessma M., Zethraeus N. Effectiveness, costs and cost-effectiveness of chiropractic care and physiotherapy compared with information and advice in the treatment of non-specific chronic low back pain: study protocol for a randomised controlled trial. Trials. 2017;18(1):613. DOI: 10.1186/ s13063-017-2351-3

9 Desai M.J., Kapural L., Petersohn J.D., Vallejo R., Menzies R., Creamer M., et al. A prospective, randomized, multicenter, open-label clinical trial comparing intradiscal biacuplasty to conventional medical management for discogenic lumbar back pain. Spine (Phila Pa 1976). 2016;41(13):1065-74. DOI: 10.1097/BRS.0000000000001412
10 Jenkins H.J., Downie A.S., Maher Ch.G., Moloney N.A., Magnussen J.S., Hancock M.J. Imaging for low back pain: is clinical use consistent with guidelines? A systematic review and meta-analysis. Spine J. 2018;18(12):2266-77. DOI: 10.1016/j.spinee.2018.05.004

11 Jiménez-Ávila J.M., Rubio-Flores E.N., González-Cisneros A.C., Guzmán-Pantoja J.E., Gutiérrez-Román E.A. Guidelines on the application of the clinical practice guideline on low back pain. Cir Cir. 2018;86(1):29-37. DOI: 10.24875/CIRU.M18000013

12 Kohat A.K., Kalita J., Ramanivas S., Misra U.K., Phadke R.V. Clinical significance of magnetic resonance imaging findings in chronic low backache. Indian J Med Res. 2017;145(6):796-803. DOI: 10.4103/ijmr. IJMR_1653_14

13 Hooten W.M., Cohen S.P. Evaluation and treatment of low back pain: a clinically focused review for primary care specialists. Mayo Clin Proc. 2015;90(12):1699-718. DOI: 10.1016/j.mayocp.2015.10.009

14 Hincapié C.A., Tomlinson G.A., Côté P., Rampersaud Y.R., Jadad A.R. Cassidy J.D. Chiropractic care and risk for acute lumbar disc herniation: a population-based self-controlled case series study. Eur Spine J. 2018;27(7):1526-37. DOI: 10.1007/s00586-017-5325-y

15 Furlan A.D., Giraldo M., Baskwil A., Irvin E., Imamura M. Massage for low-back pain. Cochrane Database Syst Rev. 2015;(9):CD001929. DOI 10.1002/14651858.CD001929.pub3 